was largely planed down by the early Tertiary seas, its flints contributing to the pebbles of the Woolwich and Reading beds.

Having pen in hand, I am induced to notice another slight watter in Mr. Irving's paper. He speaks of the Lenham sands as though they were first shown to be of Diestian age in 1888. He will find that that was the conclusion I arrived at in 1857 (Q.J.G.S. p. 328) and repeated in 1872 (Q.J.G.S. pp. 134, 478) and 1886 ("Geology," Vol. I. pp. 141, 303). The article in "Nature," 1888, to which he refers, is a friendly corroboration of the conclusion I had expressed. Nor were the sands on the Downs some miles further westward assumed to be contemporaneous "on the ground of approximate equality of altitude above the sea," but in that of position and structure.

Mr. Irving's observations about the Raised Beaches of Sussex described by me in 1858, and others in the Westleton shingle, might also call for some remarks; but these would lead me too far. I am also unable to follow Dr. Irving in the larger and more theoretical questions on which he enters, and respecting which we shall be better able to judge when he gives us, which I hope he will in some future paper, in detail the local evidence upon which his views are based.

Joseph Prestwich.

Shoreham, Kent, Sept. 10, 1890.

\title{
STANDARDS OF MEASUREMENT.
}

Sir,-Will you kindly permit me to direct the attention of the readers of the Geological M MGazine to an objectionable feature in the writings of many of our modern geologists, namely, the use, or rather misuse, of the French metrical standard of measurements instead of the English imperial standard. There are numbers of earnest students of geology who, like myself, read eagerly and carefully, as they are issued, the Quarterly Journal, Proceedings of the Geologists' Association, and the Geologrcal Magazine, but being unacquainted with the French language or their standard of weights and measures, they are unable to grasp the full import of many of the learned and highly instructive papers and articles which adorn the pages of the above-mentioned journals. These students are perfectly familiar with the English standard, and any measurement from $1 / 16$ th of an inch to a fathom, or even to a mile, furnishes at once, without any mental effort, a perfectly accurate impression of size or distance, while those given according to the French standard only convey impressions of the most indefinite kind. Moreover, when we take into consideration the fact that the papers and articles referred to are written by Englishmen, publisbed in English journals, and many of them are read before English societies, it is greatly to be deplored, not only that their usefulness is marred, but also that an important part of their contents is rendered practically unintelligible to a very large number of readers by the introduction of foreign measures and quantities. The metrical system of measures may be superior to the English imperial standard in some respects, but it is not likely that the former will ever take the place of the latter, either in England or her numerous and populous colonies, while the use of a dual system must of necessity be a fruitful source of confusion and annoyance. I must state, however, that some of the writers who use the metrical system, take the trouble to add to the measurements given in that standard, their approximate equiralents according to the imperial standard, and if all would adopt that course, or still better, reverse the order, there would be no further cause for complaint.

Keswick, Sept., 1890.

John Postlethwaite. 